\title{
The Escalada Formation: Characterization of a potential chert supply source in the Cantabrian Mountains (NW Spain) during prehistory
}

\author{
M. Natividad Fuertes-Prieto ${ }^{1}$, Esperanza Fernández-Martínez ${ }^{2}$, \\ Fernando Gómez-Fernández ${ }^{3}$, Eduardo Alonso-Herrero ${ }^{4}$, \\ Diego Herrero-Alonso ${ }^{5}$, Ana Neira-Campos ${ }^{1}$
}

1. Área de Prehistoria, Departamento de Historia, Facultad de Filosofía y Letras, Universidad de León, Campus de Vegazana s/n, 24071 León, Spain. Email: Fuertes-Prieto: n.fuertes@unileon.es;

Neira-Campos: ana.neira.campos@unileon.es

2. Área de Paleontología, Universidad de León, Spain. Email: e.fernandez@unileon.es

3. Área de Prospección e Investigación minera, Universidad de León, Spain. Email: f.gomez@unileon.es 4. Área de Edafología y Química del Suelo, Universidad de León, Spain. Email: ealoh@unileon.es

5. Universidad de Salamanca, Spain. E-mail: dherreroalonso@usal.es

\begin{abstract}
:
A study of the chert nodules found in the Escalada Formation (Carboniferous, Ponga region, Cantabrian Zone) was carried out as a means to characterise a number of lithic raw materials found in several prehistoric sites of the Cantabrian Mountains (NW Spain). This study comprises fieldwork aimed at locating the outcrops and obtaining samples. Some selected samples from two localities were used for both petrological (macroscopic and microscopic analyses from thin sections) and geochemical (X-ray fluorescence and powder diffraction) analysis. The macroscopic study shows a rather homogeneus coloration and a conchoidal fracture although two extreme types of cherts with a variety of intermediate forms can be differentiated according to the matrix composition. The microscopic analysis shows a high heterogeneity in carbonate versus silica percentage and gentle differences in some other features such as type of silica, origin of carbonates, occurrence of organic matter and type of skeletal components. The results of several geochemical analysis suggest that there are not geochemical features neither in the major elements nor in the traces that allows us to clearly distinguish between the analysed samples. All these studies allow us to define the main features of these chert nodules and to establish several types and varieties among them. Those varieties with high percentage of silica and with a more homogeneous matrix are the most suitable samples for knapping. These results together with the study of the geological and geographical location of archaeological sites suggest that the nodules from the Escalada Formation likely were lithic material supply sources used in knapping activities

When aiming to demonstrate the use of these materials at archaeological sites the sole macroscopic analysis of the pieces does not suffice; further analyses, such as those involving thin sections, are necessary. The absence of chert from Escalada Formation in some Mesolithic sites in the area was confirmed via these additional analyses.
\end{abstract}

Published by the School of History, Classics and Archaeology, University of Edinburgh ISSN: 2055-0472. URL: http://journals.ed.ac.uk/lithicstudies/

This work is licensed under a Creative Commons Attribution 2.5 UK: Scotland License. 
Keywords: lithic raw materials; carboniferous "black chert”; Cantabrian Mountains; Ponga Unit, Escalada Formation

\section{Introduction}

The potential lithic raw material supply sources in the central-western area of the Cantabrian Mountains (north of the Iberian Peninsula), especially those from Paleozoic area are poorly known (Arias et al. 2009; Tarriño et al. 2015). Thus, for some years now, a team from the University of León has been studying these potential local sources especially in relation with the study of a number of Mesolithic sites in the region (El Espertín and La Uña caves - León, Spain). It is worth noting the occurrence of radiolarite and two kinds of black chert amongst the raw materials used at these sites (Fuertes Prieto et al. 2010; Herrero 2014; Neira et al. 2015). Although the origin of the radiolarite is well known (Alba Fm, Fuertes Prieto et al. 2010), the origin of the two varieties of black chert presents major problems (see Herrero-Alonso in press). Consequently, the study of the different formations that may contain black chert is important to know the possible sources of supply of these materials for the prehistoric groups.

Following common methodological frameworks for this kind of studies (Mangado 2005; Tarriño 2006), and in addition to the analyses carried out on the archaeological materials, we also reviewed all available literature on these geological formations referencing the presence of chert. This information was used when planning our fieldwork so at to best locate the outcrops of these formations in the field. This line of research, focussed on finding and identifying potential supply sources, and obtaining reference samples, is essential for the development of future raw material studies at the regional level and which will contribute to putting together a lithotheque of known samples. This study focuses on the research in the Escalada Formation, a Carboniferous limestone locally bearing black chert nodules that outcrops in the Cantabrian Mountains. The occurrence of black chert in this formation was first noted by Calderón (1910), who refers the so-called 'sílex de Goberanes' (sic) (Gobezanes chert).

During this work, four outcrops of black chert nodules embedded in the limestone of the Escalada Formation were located, all of them in Asturias province. Two of them (GOB1 and CAL1) are located in the "Sierra de Gobezanes" area; the third one (PSI1) in the watershed, at the mountain pass of San Isidro, where the source of the Aller (northern slope) and the Porma (southern slope) rivers is located. The last one (SBF1) was found in the headwaters of the Ponga river. The macroscopic features of this chert nodules in all of the outcrops present a black shiny colour and are consistent with certain samples of the so-called 'black chert' in Mesolithic sites of the region, both on the northern slope (Arias et al. 2009) and on the southern slope, such as El Espertín and La Uña caves (Neira et al. 2015), as we have mentioned before. Therefore, an accurate characterization of the Escalada Formation chert is an essential part of the research on the exploitation of siliceous resources in the Cantabrian Mountains during prehistory. On the one hand, this will enable us to determine whether this chert was used at these Mesolithic occupations and, on the other, to incorporate a new lithology, from a regional point of view, to the map of potential raw materials.

\section{Geological context}

The Escalada Formation (Ginkel 1965) is located in the Beleño basin (Ponga Unit, Cantabrian Zone, Iberian Massif; Figure 1). It comprises massive limestones, 200-400 m thick over the Beleño Fm. in the Ponga Unit. This formation has been divided in two different Carboniferous sequences (Bahamonde et al. 2015). The first, "Escalada I", has a Vereian?mid Podolskian age, and the second, "Escalada II”, a Podolskian - early Myachokovian age. 


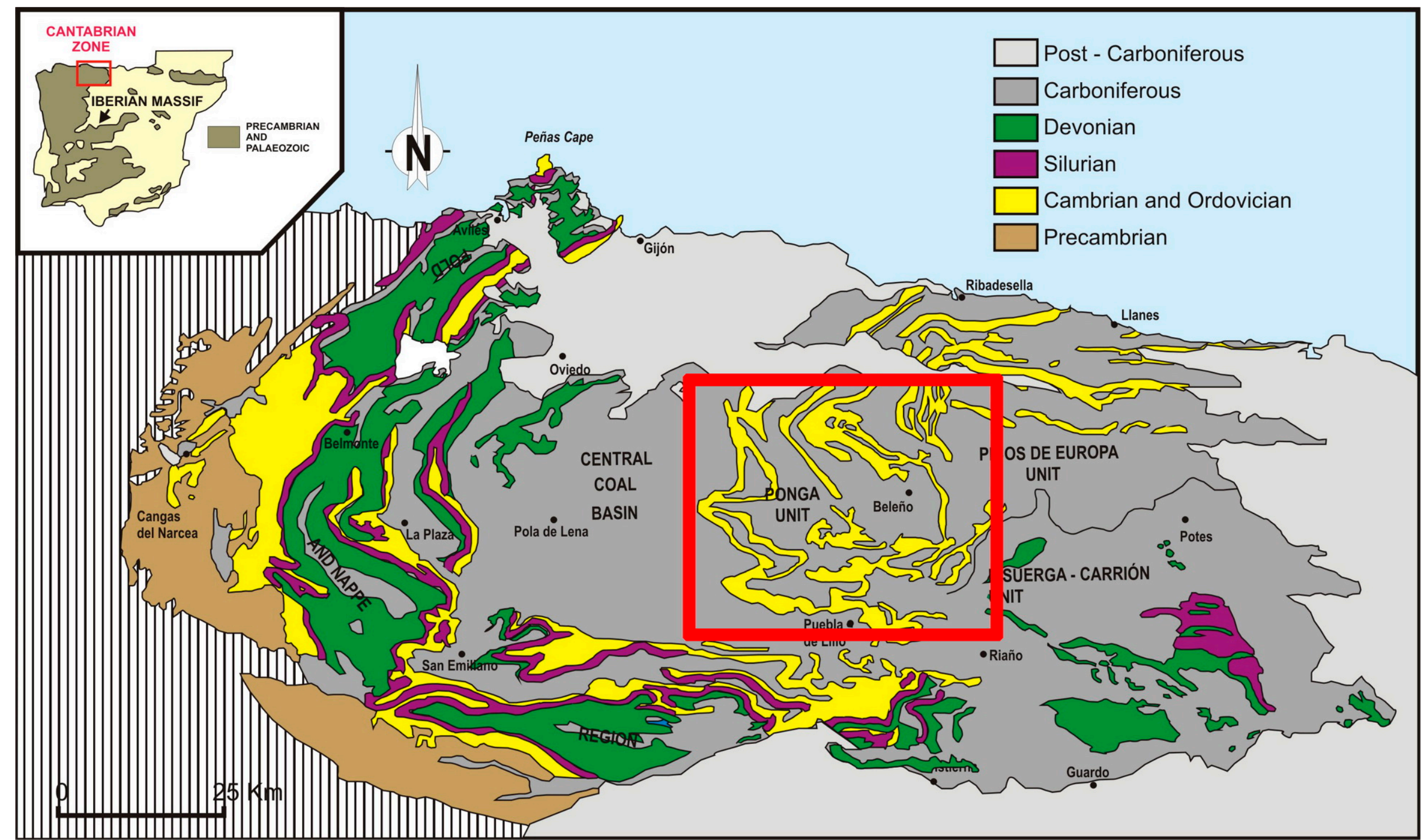

Figure 1. Lithological map of the Cantabrian Zone showing the main geological units after Julivert (1971). The red square corresponds to the region with Escalada Formation outcrops in Figure 3. 
References to the occurrence of chert in this formation are very scarce. Only two publications mentioning the presence of chert were found: firstly in Calderón's reference early in the twentieth century (Calderón 1910: 268), and lastly in the stratigraphic columns put together for the second series of the 'MAGNA' geological maps, where the occurrence of chert nodules is noted (Bahamonde Rionda 1987) (Figure 2).

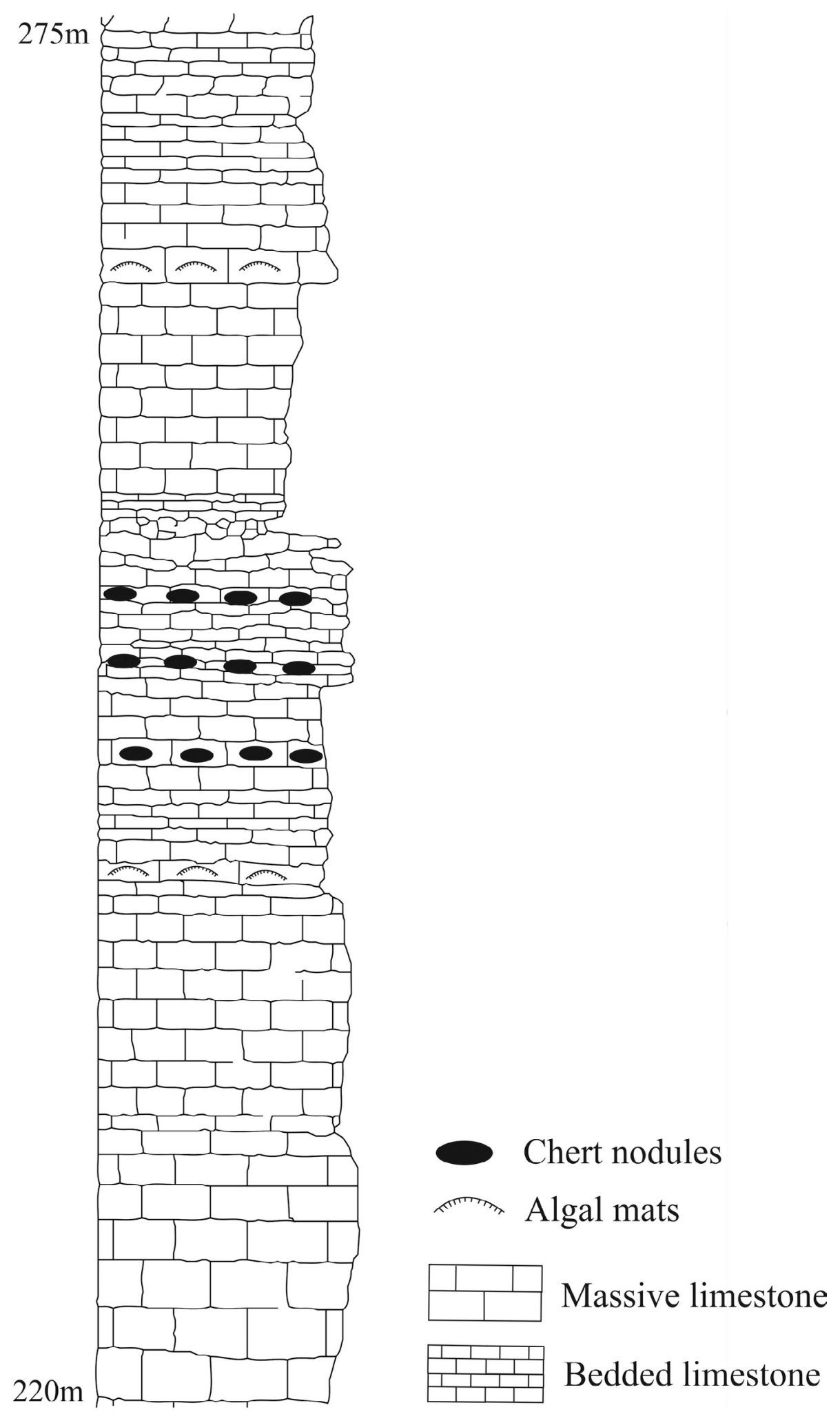

Figure 2. Stratigraphic column of the Escalada formation (modified from: Bahamonde 1987). Note the occurrence of chert nodules in the middle part of the sequence. 
Interestingly, there are other limestone formations also containing black chert silicifications in adjacent units to the Ponga Unit both eastwards and westwards (in the Central Carboniferous Basin and Picos de Europa) which are regarded as lateral equivalents to the Escalada Formation: the Levinco, Bachende and Picos de Europa Formations.

The Escalada Formation has a fairly limited geographical distribution around a 20-km radius in the direction of the Nalón and Ponga River headwaters (Figure 3). The location of this occurrence area develops towards the northern slope of the Cantabrian Mountains, in the province of Asturias. Only the southernmost point of this distribution, around the Puerto de San Isidro, is found in the slopes' boundary, meaning that some areas could in fact be a small part of the Porma River basin (southern slope).

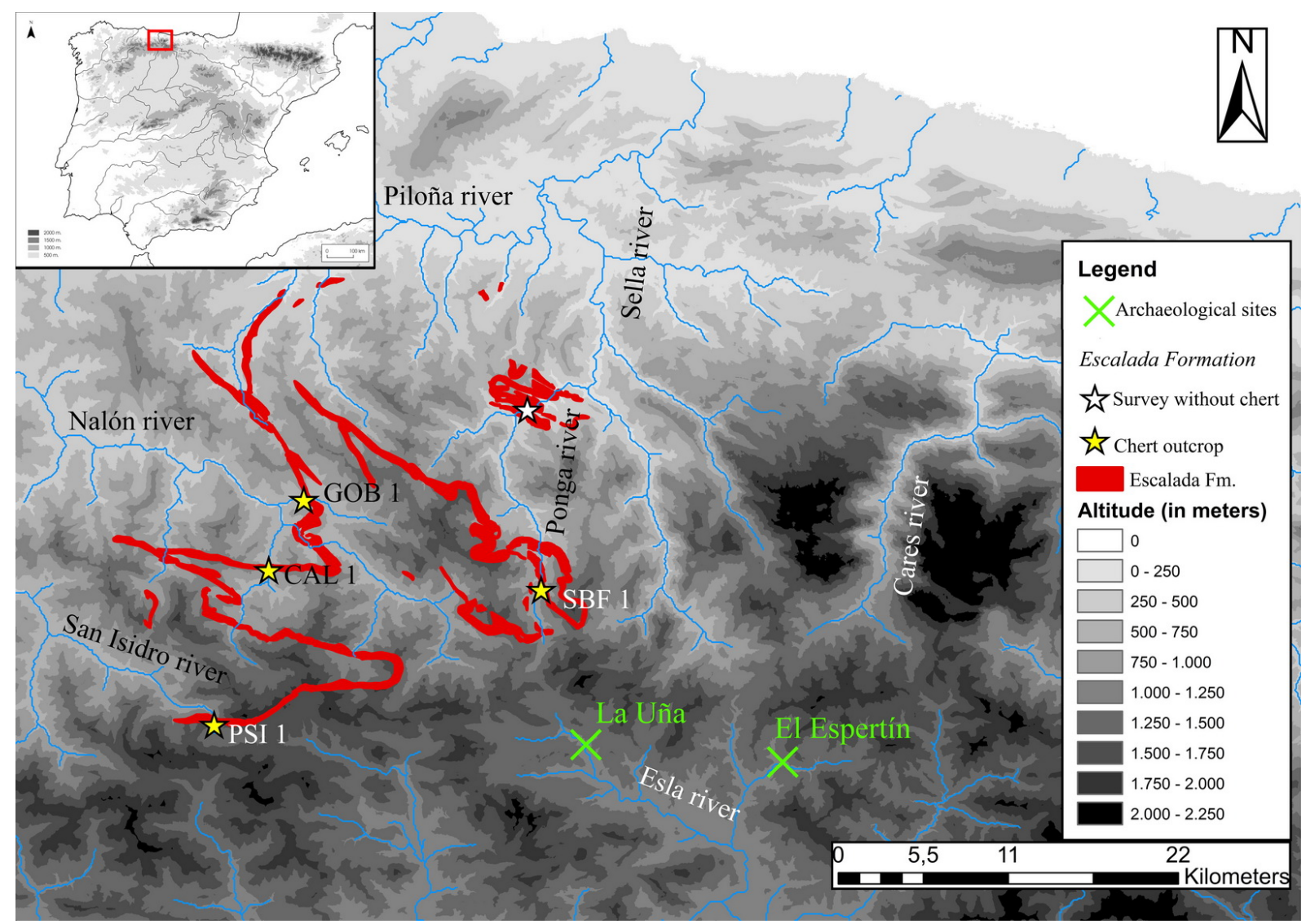

Figure 3. Distribution map of the Escalada Formation. The yellow stars show the location of the fourchert outcrops identified: Sierra de Gobezanes (GOB1), Puerto de San Isidro (PSI 1), Sobrefoz (SBF1) and Caleao (CAL1). The crosses indicate the location of the archaeological sites cited in the text (La Uña and El Espertín). (Source: altitude maps are taken from Centro Nacional de Información Geográfica-CNIG, rivers from Infraestructura de Datos Espaciales de España-IDEE and geological distribution of Escalada Fm. from Instituto Geológico y Minero de España- IGME).

\section{Geological setting and raw material}

As was previously noted, four outcrops of the Escalada Formation bearing chert nodules have been located (Figure 3). In this work we will focus on two of them: Gobezanes (GOB1) and Puerto de San Isidro (PSI), as the other two (Caleao -CAL1- and Sobrefoz -SBF1-) are still under study.

Gobezanes outcrop is situated in the headwaters of the Nalón River, an area belonging to the Asturias province. There, chert is found as sporadic and isolated or lined up nodules floating in the limestone beds (Figure 4). The nodules are different in size and show a variety of designs, from ovoid to fungiform shapes. 

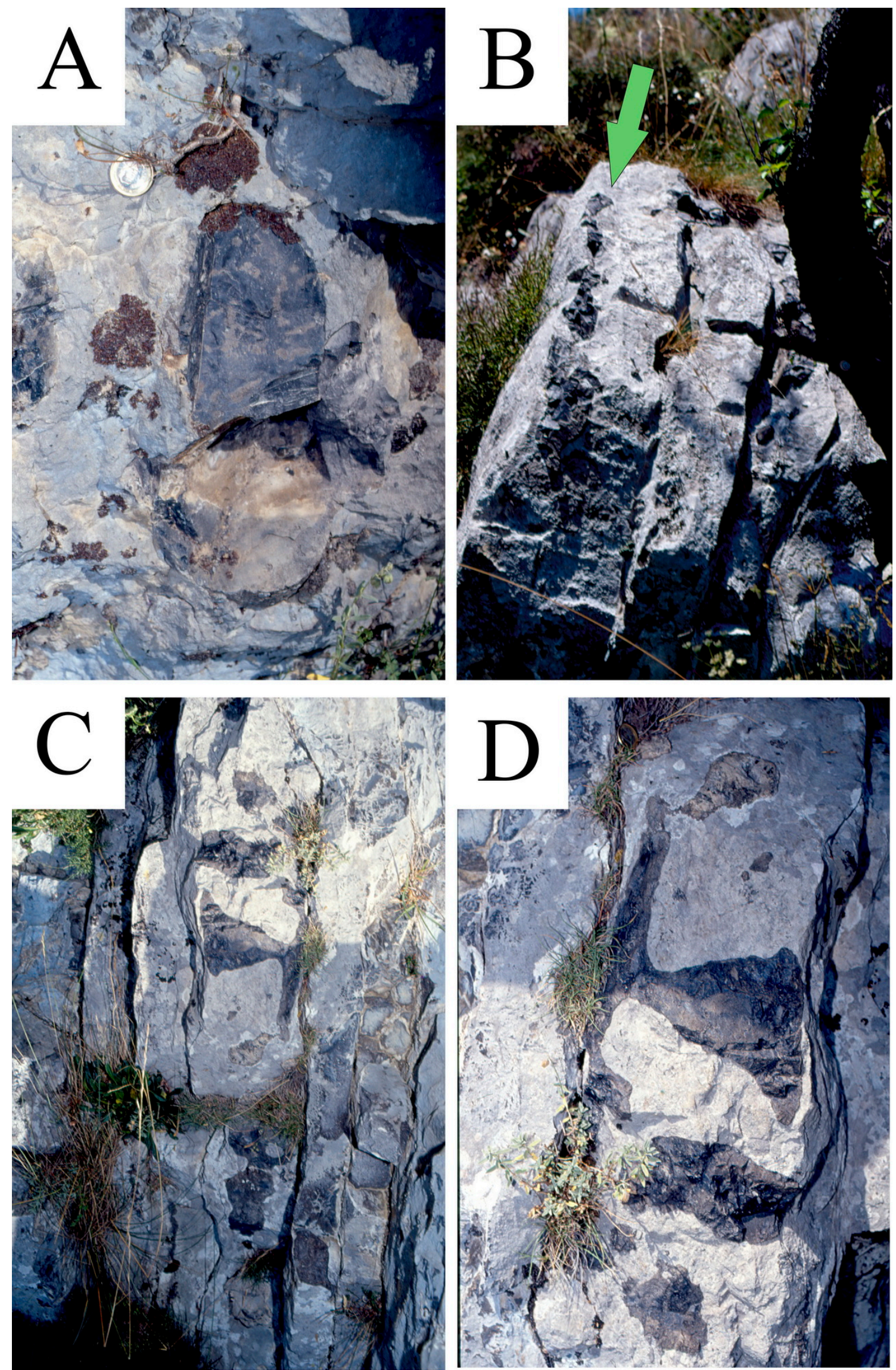

Figure 4. Chert nodules at the Gobezanes outcrop. A) Detail of a chert nodule. B and C) General view of limestone with nodules of chert imbedded on it. D) Detail of a nodule of chert of the previous image. 
The Puerto de San Isidro chert outcrop is located north of the watershed, in the Asturias province. There, the occurrence of the chert nodules has similar features than those showed in Gobezanes outcrop. Chert is quite abundant and appears in discontinuous nodules embedded in limestone (Figure 5). The nodules are also different in shape and size, but mostly show an ovoid morphology.
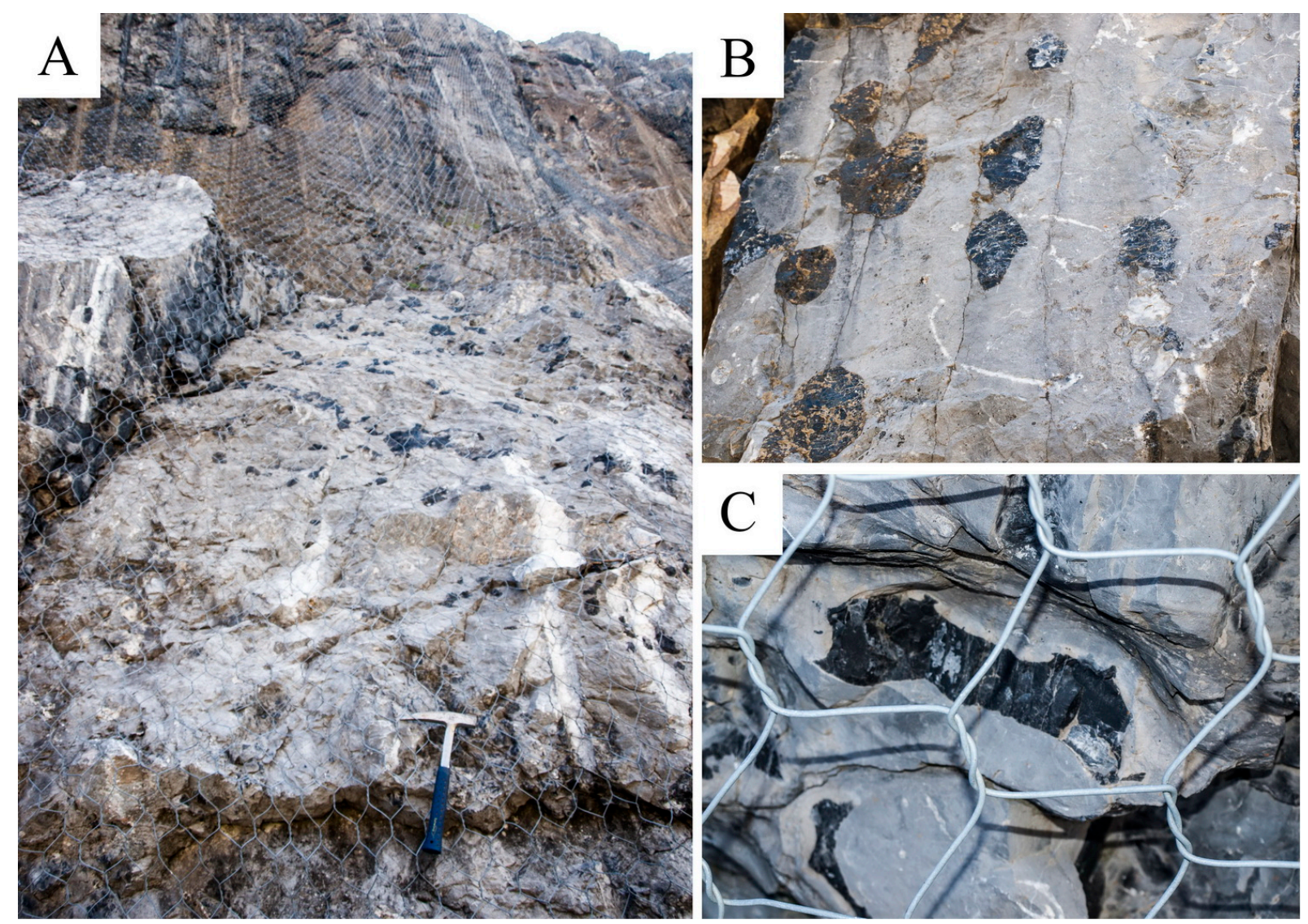

Figure 5. Chert nodules at the Puerto de San Isidro outcrop. A) Outcrop view. B) Detail of the nodules floating in the limestone. C) Detail of a nodule showing its dark colour on a fresh surface of the rock.

\section{Materials and methods}

The methodology applied includes five types of analysis:

1. Review of geological literature with references to chert and location of possible source areas.

2. Fieldwork to locate the primary position of the outcrops and obtain samples. This phase is still ongoing.

3. Macroscopic analysis on ten samples from Gobezanes (GOB1) and eight from Puerto de San Isidro (PSI1). These samples were analysed as in previous studies (Fuertes Prieto et al. 2010; 2014), entailing the recording of six general attributes: colour (using the Munsell Color 2013); pattern (arrangement of the colours); matrix (homogeneity of the pieces in terms of the presence of fracture planes, more irregular areas, etc.); appearance (gloss and transparency); cortex and alterations. The material was also examined using a Nikkon SMZ-1000 binocular magnifier and magnifications within the $8 x-80 x$ range.

4. Microscopic analysis on six thin sections (30 $\mu \mathrm{m}$ thick). Four samples (CG1, CG2, CG3, CG4) come from the Gobezanes outcrop and have been studied under the microscope using an Olympus BX51 petrographic microscope equipped with an Olympus Camedia C5050 Zoom camera. Two other thin sections (PSI-1-26, PSI-1-16) were collected at the Puerto 
de San Isidro outcrop and have been studied using a JEOL JSM-6480 scanning electron microscope (SEM), equipped with an Oxford D6679 EDS detector.

5. Four samples two from the Gobezanes (GOB1, GOB2) and two from the Puerto de San Isidro outcrops (PSI-1-27, PSI-1-23) were selected for the mineralogical and geochemical analyses. The samples were ground to fine powder using a Retsch Gmbtt MM301 zirconium mixer mill.

Mineralogical identifications were carried out on polycrystalline powder samples using a Philips diffractometer ( $\mathrm{X}^{\prime}$ Pert Pro model) equipped with a copper anode tube and a flat graphite monochromator. Step size was $0.0200^{\circ} 2 \theta$ step and the scan time $4 \mathrm{~s}$.

The chemical analyses were carried out in a Philips wavelength dispersive X-ray fluorescence spectrometer (WDS) (PW 2404 model), with a $4 \mathrm{Kw}$ power rhodium anode tube. The major elements were determined by means of a pearl obtained through fusion, with lithium tetraborate and a 10:1 ratio of flux/sample. Prior to the fusion, the loss on ignition (LOI) was calculated, calcining the sample at $975{ }^{\circ} \mathrm{C}$ for two hours. In order to determine the trace elements, the samples were prepared in a tablet pressed with 40 tonnes for two minutes. The amount of sample used was $10 \mathrm{~g}$ mixed with an Elvacite solution (4 mml for every $10 \mathrm{~g}$ of sample).

\section{Macroscopic features}

The macroscopic study of the samples shows the occurrence of similar features in all the samples. The main traits are described below:

Colour and pattern distribution: Black to dark grey colour (GLEY 1 3/N to 2.5/N - very dark grey to black). The bioclastic range is closer to dark beige. Colour changes are gradual and lenticular, with no lamination.

There is great homogeneity in pattern distribution, although some nodules have small brown patches.

Appearance: Semi shiny and opaque.

Matrix and inclusions: Heterogeneous among samples. Two studies have been carried out: de visu and under a loupe:

a) De visu study allowed us to differentiate two extreme types of cherts with a variety of forms between them.

Type 1. Silica-rich, homogeneous, very dark matrix. Clear conchoidal fracture (Figure 6 $\mathrm{A}$ and $\mathrm{B})$.

Type 2. Carbonate-rich, heterogeneous, grey shade matrix. Poor defined conchoidal fracture. Occurrence of abundant fracture planes filled with calcium carbonate. Slightly coarser and rougher to touch (Figure $6 \mathrm{C}$ and $\mathrm{D}$ ).

Fairly homogeneous cherts have been observed between these two extremes. Most of them show rich-carbonate patches, usually quite irregular in shape and size.

b) Under loupe study allowed us to differentiate three varieties of cherts:

Variety A. Deep black, completely opaque and very homogeneous matrix. No inclusions observed except for some dolomite and, or calcite idiomorphs, which can resemble quartz due to the reflected light. This variety is predominant in the Puerto de San Isidro outcrop.

Variety B. Ochre-coloured heterogeneous matrix (when in contact with water, otherwise it appears dark grey) with slight shade changes within the same range of colours. It is opaque and contains abundant bioclasts and some complete skeletons of fusulinids. This variety is predominant in the Gobezanes locality

Variety C. Black homogeneous matrix, similar to the first variety but with high porosity, possibly caused by the dissolution of carbonate crystals that have replaced the silica matrix. This variety is common in both outcrops. 

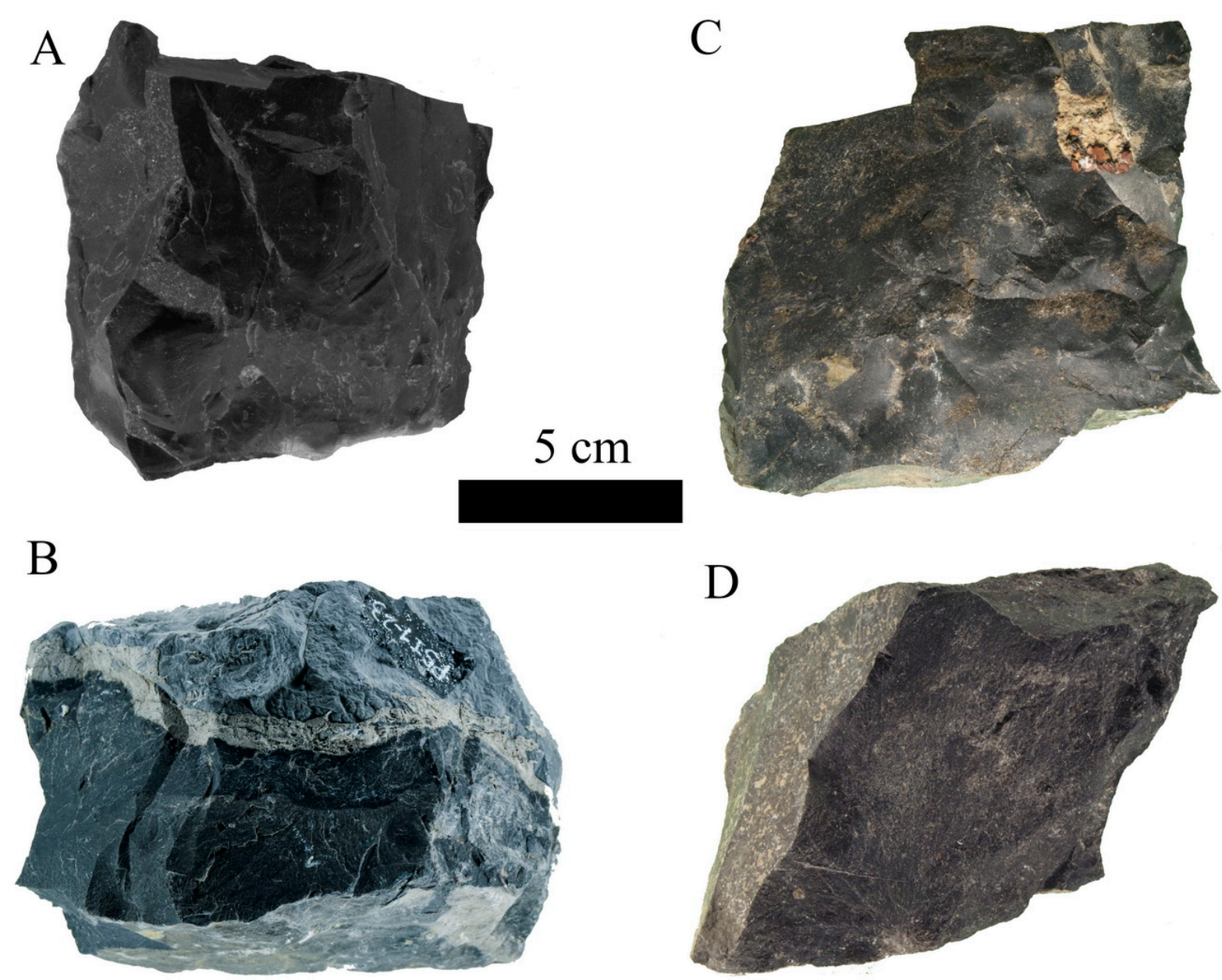

Figure 6. Chert nodules from the Escalada Formation showing matrix heterogeneity and different qualities for knapping. A: Dark chert with clear conchoidal fracture. B: Dark chert with host rock. C: nodule with small brown patches. D: dark grey variety. A, C and D: cherts from Escalada outcrop. B: chert from Puerto de San Isidro outcrop.

Variety A and B correspond to type 1, while the variety C corresponds to type 2.

Cortex: Reflects the adjacent limestone, has a fresh and rugged appearance, greyish (5 Y $5 / 1$ - grey) or whitish-beige in colour. Its thickness varies between blocks, being thin (1.2 $\mathrm{mm}$ ) when the nodule is perfectly separated from the rock. Contact between the cortex and chert itself is clear, although it has irregularities.

Alteration such as white patina has not been observed.

\section{Microscopic features}

Four thin sections from samples CG1 to CG4 were produced for the optical microscopic study. Samples CG1 and CG2 are from nodules with carbonate patches whereas samples CG3 and CG4 belong to nodules with a more homogeneous structure. This study was completed by SEM, which was applied to two polished thin sections obtained from chert nodules collected at the Puerto de San Isidro outcrop (samples PSI-1-16 and PSI-1-26). The analytical methodology is identical to that employed in previous research activities (Fuertes Prieto et al. 2010; 2014) and use the following criteria:

- Main mineral component (approximate percentages of silica and calcite).

- Degree of grouping of the calcite minerals (in aggregates and disperse).

- Presence of laminations at the microscopic level (reflecting laminations seen in hand samples or with a magnifying glass). 
- Presence or absence of organic matter (observed or inferred).

- Presence and type (high range taxa) of skeletal components.

- Secondary elements (diagenetic and post-diagenetic).

Taking into account the thin-section studies, these cherts have the following characteristics:

1. Samples show a great heterogeneity in carbonate versus silica percentage (Figure 7). This fluctuation is also observed in a single sample.

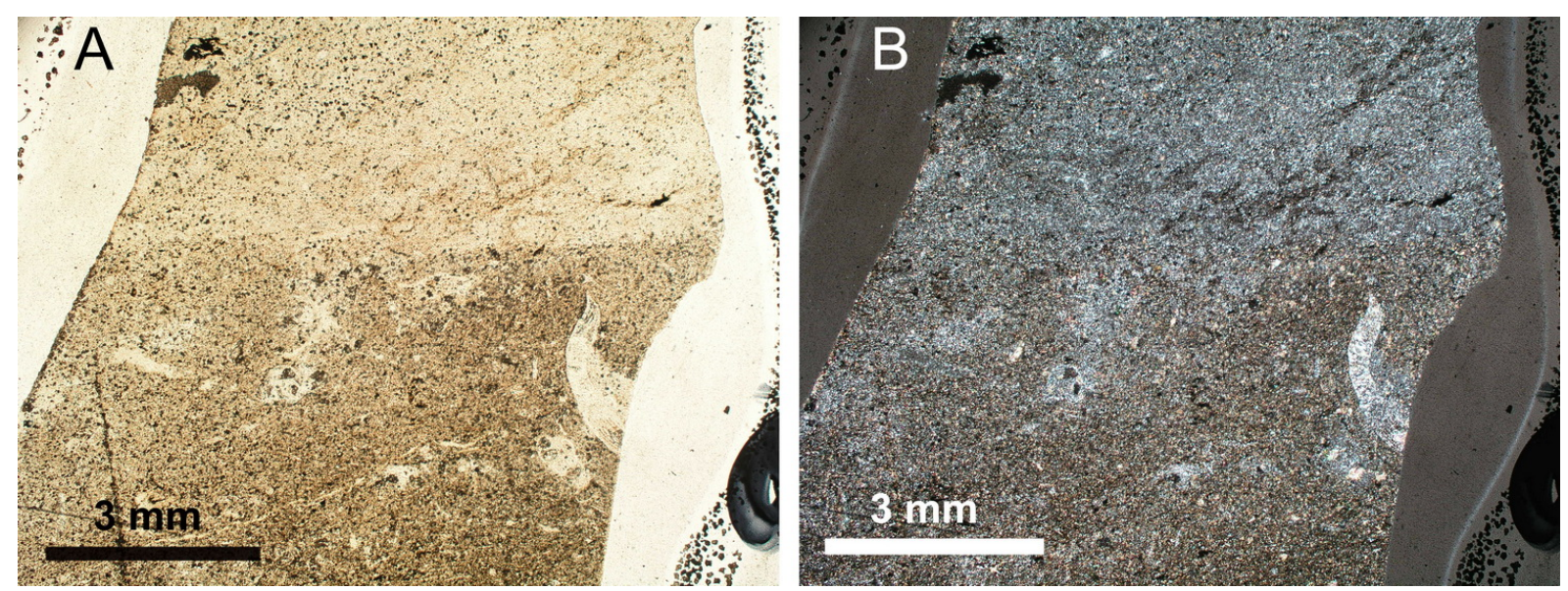

Figure 7. Microphotographs from sample CG4.The heterogeneity can be seen: the upper part more siliceous and the lower part more carbonatic. Left: parallel polarized light (ppl). Right:crossed polars(xpl).

2. Silica occurs in two forms:

a) Fine grain crystals filling gaps (authigenic silica). They are very common in sample CG1 and common in CG2 (Figure 8 - left).
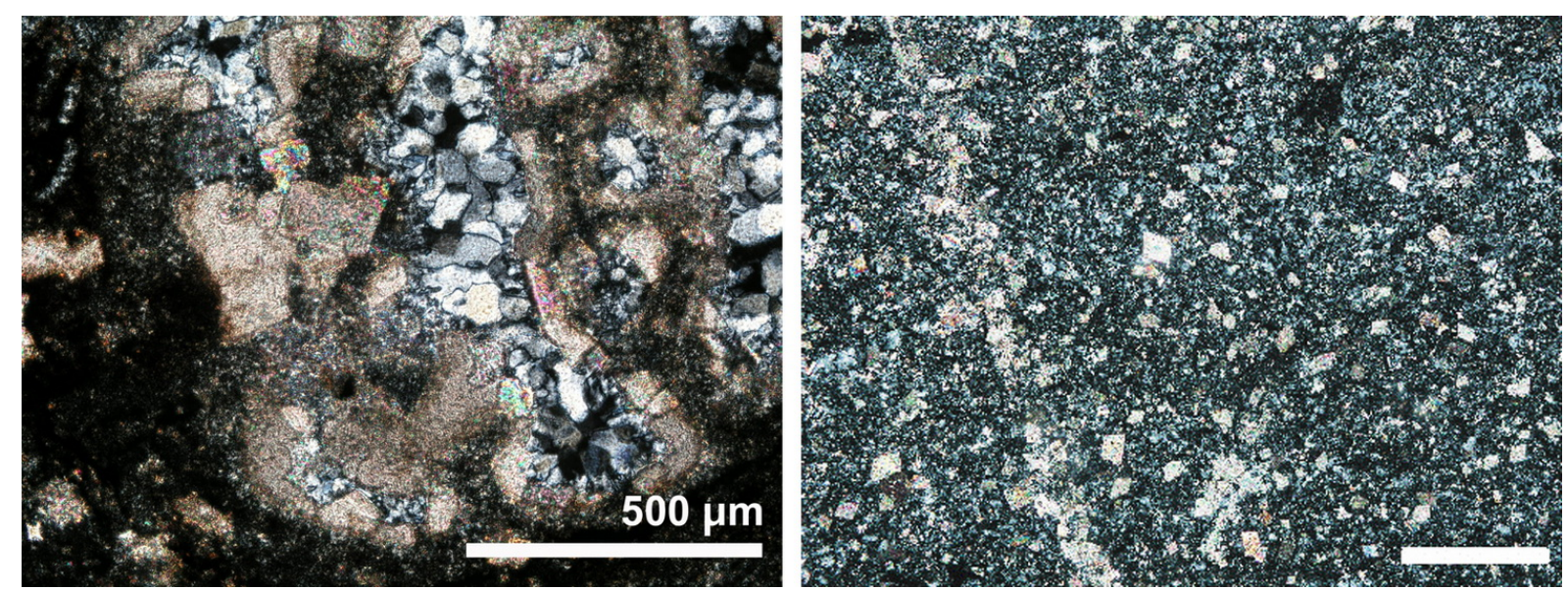

Figure 8. Left: sample CG1: skeleton filled up by quartz (xpl). Right: Sample CG3 (xpl): matrix mainly composed of microscopic silica with dolomite and calcite (scale bar: $250 \mu \mathrm{m}$ ).

b) Cryptocrystalline silica replacing previous carbonates (Figure 9) or disseminate in the matrix (Figure 8 - right). More common in slide CG4.

3. Carbonate occurs both as calcite and dolomite and it has two possible origins

a) Original calcite: generally microgranular and micritized calcite forming the organic skeletons (Figure 10).

b) Floating or contact-rhomb of idiomorphic dolomite replacing silica and carbonate (Figure 11 - left).

c) Filling fractures sparite (Figure 11 - right) 

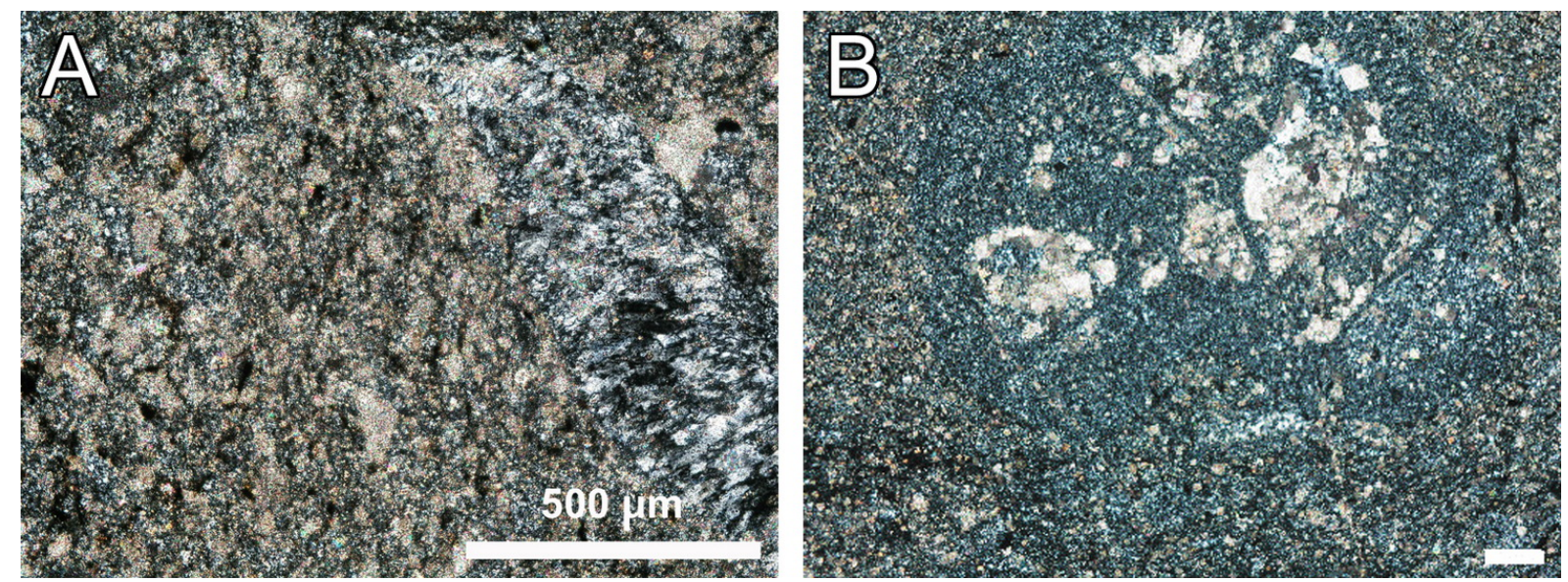

Figure 9. Cryptocrystalline silica replacing previous carbonates. Left: sample CG4 (xpl), indeterminate algae. Right: Sample CG3 (xpl) (scale bar: $250 \mu \mathrm{m})$.
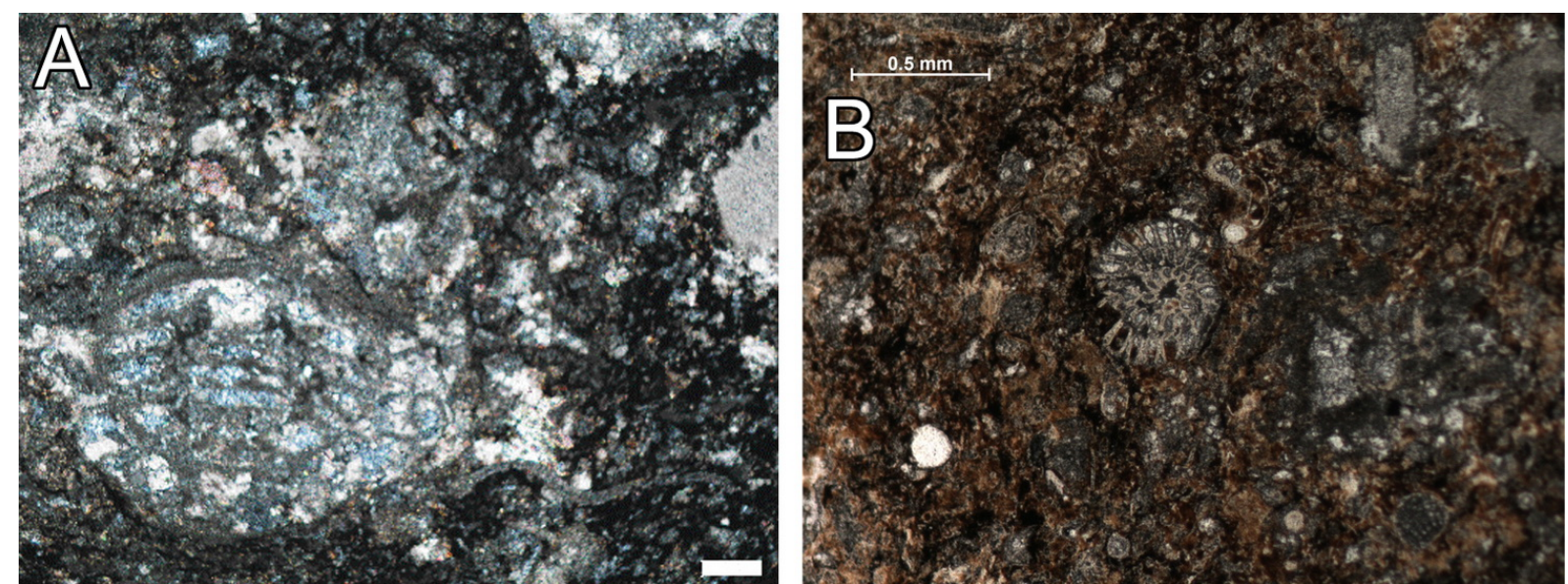

Figure 10. Original calcite forming the organic skeletons. Left: Sample CG1 (xpl), fusulinid section and calcispheres (scale bar: $250 \mu \mathrm{m}$ ). Right: Sample CG1(ppl), probably a fusulinid section (scale bar: $5 \mathrm{~mm}$ ).
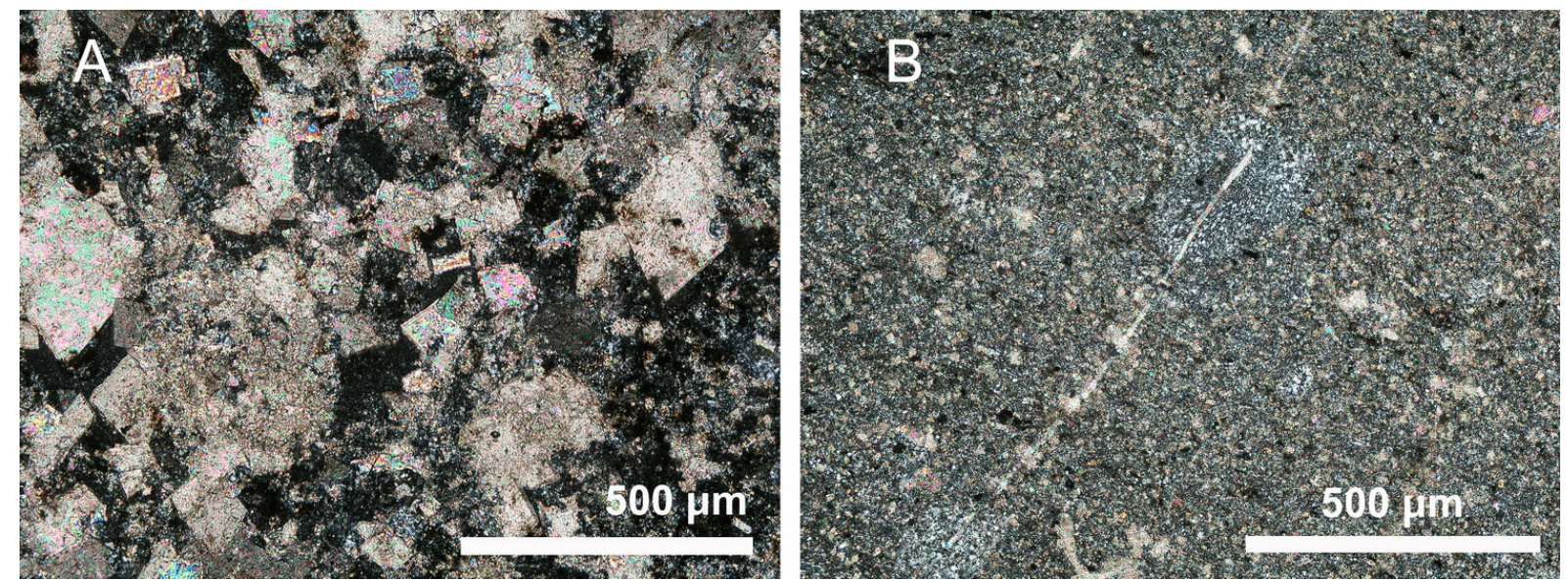

Figure 11. Left: rhombi of idiomorphic dolomite; sampleCG1 (xpl). Right: fracture filled up by sparite; sample CG3 (xpl).

4. Lack of lamination, although carbonate concentrations have been observed in certain levels and cases (Figure 12).

5. Organic matter is usually abundant (Figure 10 - right), dispersed or locally concentrated in fissures. Its content decreases in areas with abundant cryptocrystalline silica (CG4 sample). 

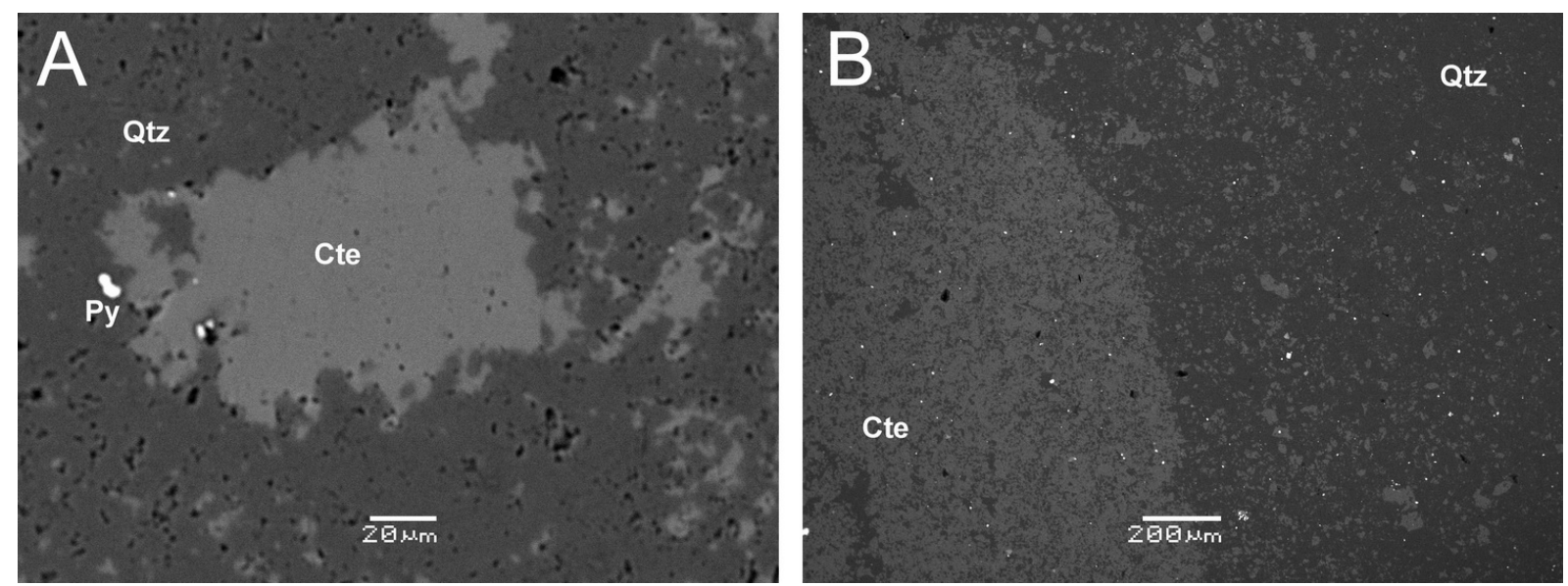

Figure 12. BSE images of thin polished sections of the Puerto de San Isidro chert. Left: Quartz (dark grey) replacing calcite crystals (light grey) (sample PSI 16) (scale bar: $20 \mu \mathrm{m}$ ). Right: Calcite- and (left-hand side of the image) quartz-predominating alternation zones (right-hand side of the image) (Sample PSI 126) (scale bar: $200 \mu \mathrm{m})$. Abbreviations: Qtz - quartz; Cte - calcite; Py - pyrite.

6. Skeletal fraction mainly made up of bioclasts and of complete skeleton in a lesser degree. Fauna is composed of equinoderms, foraminifera (fusulinids), green algae, phylloid algae, sponges (usually represented by dissolved spicules), ostracod remains, gastropods, and bryozoan (Figures 8 left, 9 and 10). In areas with cryptocrystalline silica some skeletons appear complete.

7. Secondary elements: area with an accumulation of insolubles.

\section{X-ray fluorescence (XRF) and X-ray powder diffraction (XRD) analysis}

Four samples, two from the Gobezanes and two from the Puerto de San Isidro outcrops, have been analysed.

In order to contrast the microscopic study carried out previously, we thoroughly analyzed the FRX geochemical data and carried out a quantification of the mineralogy of the samples (Table 1), assuming the following:

- All the content in $\mathrm{SiO}_{2}$ corresponds to quartz.

- All the magnesium derives from the dolomite.

The $\mathrm{Mg}$ at./Ca at. relationship in the dolomite $=1$. This relationship corresponds to the stoichiometry of this mineral and is very similar to the analyses of epigenetic dolomites from the Cantabrian Mountains referenced in the bibliography (Gómez-Fernández et al. 1993).

According to the above, the essential minerals of the samples analysed are the following: quartz is very predominant (between 90.44 and 91.64\%) in terms of the other minerals, calcite (between 2.76 and 7.04\%) and dolomite (between 1.11 and 4.34\%). The analysis results also reveal the very minor presence of other silicates, suggested by the $\mathrm{Al}$, $\mathrm{Na}$ and $\mathrm{K}$ values, although this is not considered relevant from a quantitative point of view.

The presence of trace elements, $\mathrm{Co}, \mathrm{Ni}, \mathrm{Cu}, \mathrm{Zn}, \mathrm{Se}, \mathrm{Cd}, \mathrm{Sb}, \mathrm{Mo}, \mathrm{Pb}$ to be precise, is interpreted as being linked to the presence of sulphurs, possibly diagenetic.

Following this, on the one hand the DRX study shows the presence of pyrite in very low quantities, and, on the other, the presence of sulphurs (sphalerite and pyrite) has been noted using an SEM in samples from the Puerto de San Isidro.

Lastly, it seems that resistates such as xenotime, celestine-barite and chromite could have reached the sedimentation basin, which would explain the rest of the significant values obtained.

There are not geochemical features neither in the major elements nor in the traces that allow us to clearly distinguish between the four analysed samples (Table 1). 
Table 1. XRF analysis of major and trace elements and estimated quantification of essential minerals.

\begin{tabular}{|c|c|c|c|c|}
\hline Major elements & PSI1-17 & PSI1-23 & GOB1 & GOB2 \\
\hline$\% \mathrm{SiO}_{2}$ & 91.64 & 91.33 & 90.75 & 90.44 \\
\hline$\% \mathrm{Al}_{2} \mathrm{O}_{3}$ & 0.28 & 0.28 & 0.25 & 0.41 \\
\hline$\% \mathrm{Fe}_{2} \mathrm{O}_{3}$ & 0.19 & 0.13 & 0.11 & 0.13 \\
\hline$\% \mathrm{MnO}$ & 0.01 & 0.01 & 0.00 & 0.00 \\
\hline$\% \mathrm{MgO}$ & 0.95 & 0.92 & 0.87 & 0.24 \\
\hline$\% \mathrm{CaO}$ & 2.87 & 3.33 & 3.46 & 4.28 \\
\hline$\% \mathrm{Na}_{2} \mathrm{O}$ & 0.08 & 0.08 & 0.09 & 0.10 \\
\hline$\% \mathrm{~K}_{2} \mathrm{O}$ & 0.04 & 0.05 & 0.05 & 0.08 \\
\hline$\% \mathrm{TiO} 2$ & 0.01 & 0.01 & 0.01 & 0.01 \\
\hline$\% \mathrm{P}_{2} \mathrm{O}_{5}$ & 0.05 & 0.05 & 0.01 & 0.01 \\
\hline \% L.O.I. & 3.38 & 3.61 & 4.22 & 4.11 \\
\hline$\%$ Total & 99.50 & 99.81 & 99.83 & 99.82 \\
\hline Trace elements & PSI1-17 & PSI1-23 & GOB1 & GOB2 \\
\hline$V(p p m)$ & 18.6 & 3.3 & 8.9 & 10.5 \\
\hline $\mathrm{Cr}(\mathrm{ppm})$ & 112.6 & 20 & 56.6 & 83.2 \\
\hline Co (ppm) & 3.5 & 3.9 & $<3$ & $<3$ \\
\hline $\mathrm{Ni}(\mathrm{ppm})$ & 12.1 & 9.6 & 3.4 & 2.9 \\
\hline $\mathrm{Cu}$ (ppm) & 5.7 & 4.2 & 2.1 & $<2$ \\
\hline Zn (ppm) & 4.1 & 6.2 & $<1$ & 74.7 \\
\hline Se (ppm) & 1.7 & 2 & 1.2 & 1.1 \\
\hline $\mathrm{Br}(\mathrm{ppm})$ & 1 & $<1$ & 1.5 & 1.1 \\
\hline $\mathrm{Rb}(p p m)$ & 5.5 & 5.3 & 4.4 & 5 \\
\hline Sr (ppm) & 60.8 & 64 & 43.1 & 41.9 \\
\hline$Y(p p m)$ & 11.3 & 10.8 & 8.1 & 8.9 \\
\hline Mo (ppm) & 2.1 & 1.1 & 1.2 & 1.2 \\
\hline $\mathrm{Cd}(\mathrm{ppm})$ & $<3$ & $<3$ & $<3$ & 3.9 \\
\hline Sn (ppm) & $<2$ & 2.5 & $<2$ & $<2$ \\
\hline $\mathrm{Sb}(\mathrm{ppm})$ & $<3$ & 4.4 & $<3$ & $<3$ \\
\hline Te (ppm) & 3.5 & $<3$ & 3.2 & 3 \\
\hline Ba (ppm) & 10.6 & 11.3 & $<8$ & $<8$ \\
\hline Ce (ppm) & $<7$ & 7.5 & 7.1 & 9.9 \\
\hline $\mathrm{Nd}(\mathrm{ppm})$ & $<4$ & $<4$ & 4.6 & $<4$ \\
\hline $\mathrm{Hf}$ (ppm) & 3.7 & $<3$ & 3 & 4.1 \\
\hline W (ppm) & $<2$ & $<2$ & 2 & 2.7 \\
\hline TI (ppm) & $<2$ & $<2$ & $<2$ & 2.1 \\
\hline $\mathrm{Pb}(\mathrm{ppm})$ & 14.2 & 14.1 & 17.3 & 17 \\
\hline U (ppm) & 4 & 2.6 & 1.5 & 2 \\
\hline$\%$ Minerals & PSI1-17 & PSI1-23 & GOB1 & GOB2 \\
\hline \% Quartz & 91.64 & 91.33 & 90.75 & 90.44 \\
\hline \% Dolomite & 4.34 & 4.20 & 3.97 & 1.11 \\
\hline$\%$ Calcite & 2.76 & 3.67 & 4.03 & 7.04 \\
\hline \% Total & 98.74 & 99.21 & 98.75 & 98.59 \\
\hline
\end{tabular}

The diffractograms also show a great mineralogical similarity among the four samples (Figure 13). 


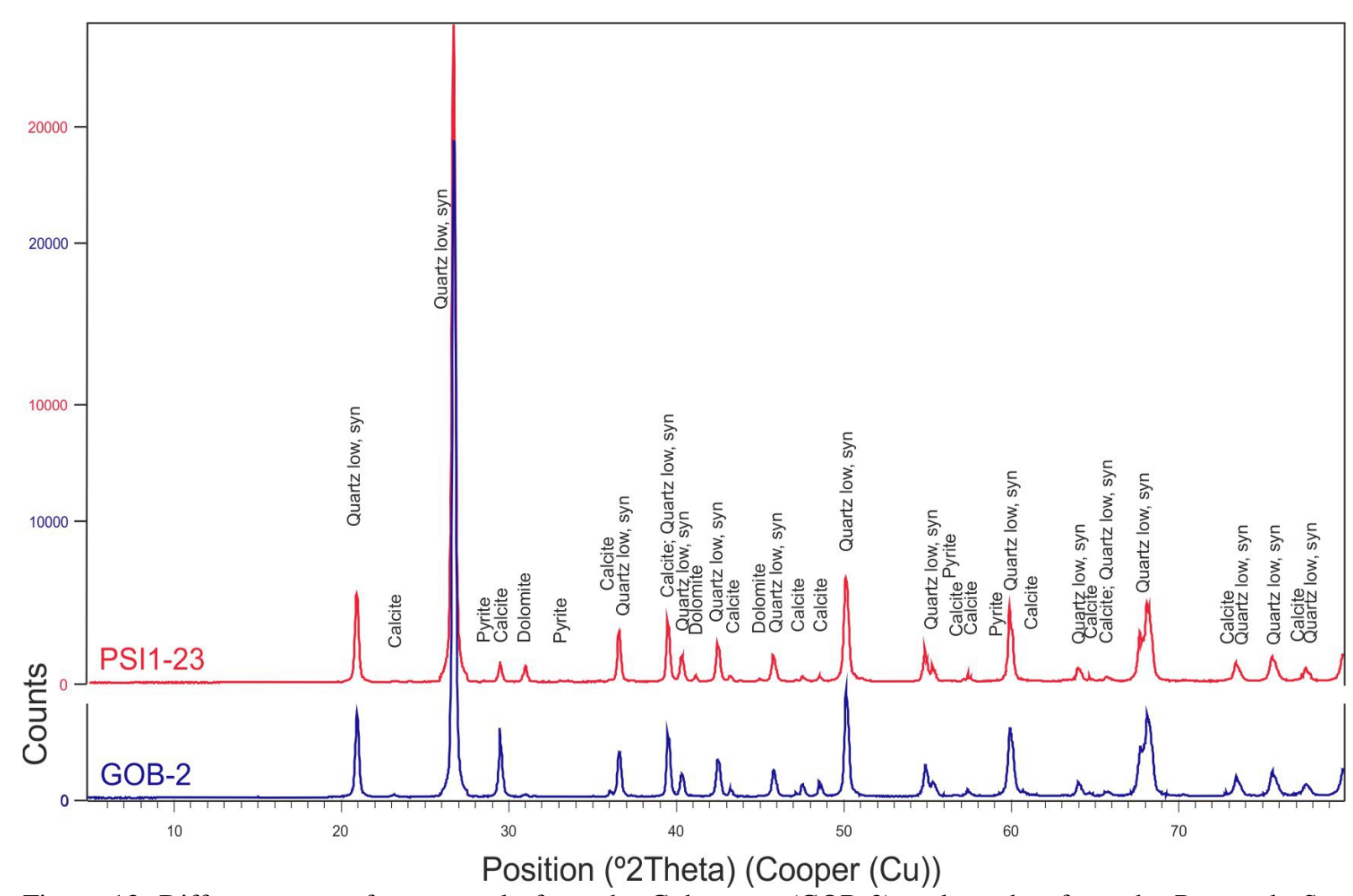

Figure 13. Diffractograms of one sample from the Gobezanes (GOB-2) and another from the Puerto de San Isidro (PSI-1-23) outcrops.

\section{Presence in archaeological context?}

As has already been noted, taking into account the data derived from the macroscopic study of the material, the Escalada chert has some similarities with some of the varieties of 'black chert' identified at the cave sites of La Uña and El Espertín (Neira et al. 2015). Both caves are located at the source of the Esla River, not far from the mountain passes that connect to the northern slope, although in different contexts. Whereas La Uña is located in the Esla valley itself, in an area with good visibility, 4.5-5 km from the Ventaniella pass, which gives access to the Ponga River, El Espertín instead is found in a secondary and orographically more secluded valley, providing it with less visibility and involving good knowledge of the area. The nearest pass connecting the northern slope is El Pontón, around 10 $\mathrm{km}$ away, representing the connecting way to the Sella River. Both are small caves and would have been used seasonally during the Mesolithic. Consequently, the analysis of the origin of the materials used at these sites can provide interesting data on lithic-procurement strategies and even on the mobility of these hunter-gatherer populations.

With regard to El Espertín, the closest limestone from the Escalada Formation (according to geological maps and regardless of whether there is chert in those specific points) is found about $18 \mathrm{~km}$ away as the crow flies (Figure 3). If we, however, consider the most feasible movement patterns for this area through the valleys and passes connecting both slopes, the closest pass to El Espertín is, as mentioned above, the Puerto de Pontón, towards the Sella River. Through this route, access to the Escalada Formation outcrops actually takes place through its tributary, the Ponga, a few kilometres further down, which would represent a c. $30-\mathrm{km}$ distance as the crow flies from the cave. If we consider the other possible route to the Escalada Formation limestone, through the Ventaniella pass, this would require covering a 30-km distance to the cave. 
With regard to La Uña cave, it is closer to the Escalada limestones of the Ponga headwaters, a river that provides access to the nearby Ventaniella pass (Figure 3).

At El Espertín the archaeological varieties of chert were petrologically characterized through the use of thin sections, from which two groups have been defined: 'black laminated chert' and 'black non-laminated chert' (Fuertes Prieto et al. 2010). The comparison of the thin sections of both varieties with those of the Escalada chert has shown that they are not the same lithology. The difference between the Escalada and the black laminated cherts is the absence of lamination in the former. In terms of the non-laminated chert, at the macroscopic level, the latter has an almost vitreous shine (absent in the Escalada chert); in thin section, there are no fusulines, ostracods, bryozoans nor algae, as well as detritic quartz.

Therefore, we can say that the Escalada formation chert was not found during the Mesolithic occupations of El Espertín Cave, as far as we know for the moment.

As for La Uña Cave, the petrological study is in progress and the comparison between the thin samples of the different varieties of archaeological chert and those of the Escalada chert may confirm whether it was used or not. Analysis by XRD and XRF of archaeological samples from these site or from other archaeological contexts, will contribute a new element to further these comparisons.

Evidently, verifying the use of black chert from Escalada will only be possible by comparing the thin sections of the chert used at these archaeological sites. The occupations of the many caves located downstream the Nalón and Sella could have used the boulders displaced by these rivers.

\section{Discussion and conclusions}

This work has characterised the chert found in the Escalada Formation. This is one of the varieties of Paleozoic black chert (Carboniferous) found on the central-western area of the Cantabrian Mountains. The geological and geographical distribution of this limestone formation on the northern slopes of the Cantabrian Mountains, around the Nalón and Ponga River headwaters needs highlighting. The occurrence of chert in this formation, however, is not ubiquitous. We have noted the appearance of chert nodules in four outcrops linked to the sources of the Nalón and Ponga Rivers. The distribution range of the chert boulders in a secondary or derived position could extend this area towards the middle and lower sections of the Nalón River and also in Ponga-Sella River zone.

The analyses carried out on material from two of the outcrops show that there are great similarities between them: nodules embedded in the limestone with various shapes and sizes, but, in many cases, with a minimum size suitable for knapping.

There are nodules with a very homogeneous matrix, very dark and a very clear conchoidal fracture, which increases their quality for knapping. These are the CG3 and CG4 thin-section samples, which match the 1 and 2 varieties in the analysis using binocular magnifiers. Others are very rich in carbonate, sometimes grayer in shade and less well-defined conchoidal fractures (CG1 sample and variety 3 using binocular magnifiers), decreasing their potential quality for knapping. The presence of fracture planes filled with calcium carbonate, quite abundant in most of the samples, is another important factor that directly affects the heterogeneity of these nodules.

Given the minimum suitable size for the knapping of the nodules, the predominant conchoidal fracture, but bearing in mind the heterogeneity of the blocks and the abundant internal fracture planes, we can say that the potential quality of this type of chert for the knapping is average in nature and is thus suitable for general knapping processes.

The fact that they are embedded in limestone does not favour their direct collection. However, the erosion to which these outcroups are subjected to, leads to the release of the 
chert nodules, which can then be easily accessed at the bottom of the valley, and are also transported and deposited as boulders further downstream. In short, the direct collection of these blocks of chert within their formation context would be feasible provided that a process of in situ dismantling of the host rock affects the particular location. It is assumed that the transport processes and the erosion of these nodules downstream will give rise to their wear, rounding and selection. These processes would increase the availability of these blocks in a derived position within the alluvial contexts of the Nalón and Ponga-Sella Rivers.

The basic features allowing distinguishing the chert from the Escalada Formation are:

- In general, a dark black colour (GLEY 1 3/N to 2.5/N). Some very bioclastic zones have beige colourations.

- Heterogeneous matrix with lenticular variation and gradual contact between them. No lamination.

- Bioclast of fusulines, ostracods, algae and sponges.

- Abundant fracture planes mostly cemented by calcite.

- Absence of white patina.

The use of this material for knapping could have been feasible during prehistoric times. In order to assess such a use, relying solely on a macroscopic analysis will not suffice, given that the overall appearance of the different varieties of black chert in this area can sometimes be very similar. It is therefore necessary to carry out other analytical procedures such as the microscopic study of thin sections.

\section{Acknowledgements}

This study was supported by funds from project AF-87 “Análisis de industrias líticas prehistóricas: materias primas y tecnología” of the Vicerrectorado de Investigación (Universidad de León, Spain).

\section{References}

Arias Cabal, P., Fernández, P., Marcos, C., \& Rodríguez I. 2009, The elusive flint: Raw materials and lithic technology in the Mesolithic of eastern Asturias, Spain. In: Mesolithic Horizons: Papers Presented at the Seventh International Conference on the Mesolithic in Europe. Belfast 2009 (Woodman, P. and Schulting Eds.), Oxbow Books. Oxford: p. 860-672.

Bahamonde Rionda, J.R. 1987, Columna estratigráfica Puebla de Lillo 14-6 (79). Instituto Geológico y Minero de España, Madrid. (in Spanish) ("Estratigraphical column Puebla de Lillo 14-6 (79)").

URL: http://info.igme.es/cartografiadigital/sidimagenes/magna/20079/Columnas/Colum nas.pdf

Bahamonde, J.R.; Merino-Tomé, O.; Della Porta, G. and Villa, E. 2015, Pennsylvanian carbonate platforms adjacent to deltaic systems in an active marine foreland basin (Escalada Fm., Cantabrian Zone, NW Spain). Basin Research, 27: 208-229. doi:10.1111/bre.12068

Calderón, S. 1910, Los minerales de España. (2 volumes) Junta para la Ampliación de Estudios e Investigaciones Científicas, Madrid, Vol. 1, 416 p., Vol. 2, 561 p. (in Spanish) ("The minerals of Spain") 
Fuertes Prieto, M. N., Neira Campos, A., Gómez Fernández, F., Alonso Herrero, E. \& Fernández Martínez, E. 2010, Caracterización de las materias primas líticas del yacimiento Mesolítico de El Espertín (León). In: Minerales y rocas en las sociedades de la Prehistoria, (Domínguez-Bella, S., Ramos Muñoz, J, Gutiérrez López, J.M. \& Pérez Rodríguez, M., Eds.), Grupo de Investigación HUM-440, Universidad de Cádiz, Cádiz: p. 169-184. (in Spanish) ("Characterization of lithic raw materials from the Mesolithic site of ‘El Espertín’ (León, Spain)")

Fuertes Prieto, M. N., Neira Campos, A., Fernández Martínez, E., Gómez Fernández, F. \& Alonso Herrero, E. 2014, "Mucientes Chert" in the Northern Iberian Plateau (Spain). Journal of Lithic Studies, 1(1): 117-135. doi:10.2218/jls.v1i1.785

Ginkel, A.C. Van 1965, Carboniferous fusulinids from the Cantabrian Mountains (Spain). Leidse Geologische Medelingen, 34: 5-225.

Gómez-Fernández, F., Escayo, M.A., Alonso, J.A., Seebold, I. 1993, Caracterización y origen de las dolomías del sector sudeste de Picos de Europa (Norte de España). Estudios Geológicos, 49: 343-350. (in Spanish) ("Characterization and origin of dolomites of the southeast area of Picos de Europa (North of Spain)”)

Herrero, D. 2014, El nivel III de la cueva de La Uña (Acebedo, León): Análisis tecnológico de la industria retocada y aprovisionamiento de materias primas. CKQ (Estudios de Cuaternario / Kuaternario Ikasketak / Quaternary Studies), 4: 15-26. (in Spanish) ("The layer III of La Uña cave (Acebedo, León): Technology analysis of retouched industry and supply of raw materials")

Herrero-Alonso, D. in press, El chert paleozoico de la Cordillera Cantábrica ( $\mathrm{N}$ de España). In: JIA 2015. VIII Jornadas de Jóvenes en Investigación Arqueológica. Lisboa. (Coelho, I.P., Torres, J.B., Gil, L.S., Ramos, T., Eds.), Centro de História d’Aquém e d’Além-Mar, Faculdade de Ciências Sociais e Humanas, Universidade Nova de Lisboa \& Universidade dos Açores and Instituto de Estudos Medievais, Faculdade de Ciências Sociais e Humanas, Universidade Nova de Lisboa (CHAM-FCSH/UNL-UAç e IEMFCSH/UNL), Lisbon, 18 p. (in Spanish) ("The Paleozoic chert in Cantabrian Range (North of Spain)”)

Julivert, M. 1971, Décollement tectonics in the Hercynian Cordillera of the northwest Spain. American Journal of Science, 270: 1-29. (in French) ("Hercynian tectonics detachment in the Mountains of the northwest Spain”). doi:10.2475/ajs.270.1.1

Mangado, X., 2005, La caracterización y el aprovisionamiento de los recursos abióticos en la Prehistoria de Cataluña: Las materias primas silíceas del Paleolítico Superior Final y el Epipaleolítico, BAR International Series Vol. 1420, Archaeopress, Oxford, 205 p. (in Spanish) ("Characterisation and abiotic resource provisioning in Prehistory of Catalonia: Siliceous raw materials from the Final Upper Paleolithic and the Mesolithic”)

Munsell Color 2013, Munsell soil-color charts with genuine Munsell color chips (2009 Edition). Grand Rapids, Minessotta, 18 p.

Neira, A., Fuertes, N. \& Herrero, D. 2015, The Mesolithic with geometrics south of the 'Picos de Europa' (Northern Iberian Peninsula): The main characteristics of the lithic industry and raw material procurement. Quaternary International, 402: 90-99. doi:10.1016/j.quaint.2015.10.065 
Tarriño, A. 2006, El sílex en la Cuenca Vasco-Cantábrica y Pirineo Navarro.

Caracterización y su aprovechamiento en la Prehistoria, Monografías $n^{0} 21$, Museo Nacional y Centro de Investigación de Altamira, Madrid, 264 p. (in Spanish) ("Chert in the Basque-Cantabrian Basin. Characterisation and procurement in the Prehistory”)

Tarriño, A., Elorrieta, I. \& García Rojas, M. 2015, Flint as raw material in prehistoric times: Cantabrian Mountain and Western Pyrenees data. Quaternary International, 364: 94108. doi:10.1016/j.quaint.2014.10.061 